\title{
PARAMETERIZATIONS OF THE VON BERTALANFFY MODEL FOR DESCRIPTION OF GROWTH CURVES
}

\author{
Felipe Augusto FERNANDES ${ }^{1}$ \\ Édipo Menezes da SILVA ${ }^{1}$ \\ Kelly Pereira de LIMA $^{1}$ \\ Sérgio Alberto JANE ${ }^{2}$ \\ Tales Jesus FERNANDES ${ }^{1}$ \\ Joel Augusto MUNIZ ${ }^{1}$
}

- ABSTRACT: The growth curves of animals, in general, have an "S" shape, also known as sigmoidal curves. This type of curve is well fitted by nonlinear regression models, including von Bertalanffy's model, which has been widely applied in several areas, being presented in literature through different parameterizations, which in practice, can complicate its understanding, affect nonlinearity measures and inferences about parameters. To quantify the nonlinearity present in a Bates and Watts model, a geometric concept of curvature has been used. The aim of this work was to analytically develop three parameterizations of the von Bertalanffy's nonlinear model referring to its nonlinearity, implications for inferences and to establish relationships between parameters in the different ways of expressing the models. These parameterizations were adjusted to the growth data of sheep. For each parameterization, the intrinsic and parametric curvature measurements described by Bates and Watts were calculated. The parameterization choice affects nonlinearity measures, consequently, influences the reliability and inferences about estimated parameters. The forms most used in literature showed the greatest deviations from linearity, showing the importance of analyzing these measures in any growth curve study. Parameterization should be used in which the $b$ estimate represents the abscissa of the inflection point, as it presents minor linearity deviations and direct biological interpretation for all parameters.

\footnotetext{
${ }^{1}$ Universidade Federal de Lavras - UFLA, Departamento de Estatística, Programa de PósGraduação em Estatística e Experimentação Agropecuária, Caixa Postal 3037, CEP: 37200900, Lavras, MG, Brasil. E-mails: fernandesfelipest@gmail.com; ediposvm01@gmail.com; kelly_limaadm@hotmail.com; serztjane@gmail.com; tales.jfernandes@ufla.br; joamuniz@ufla.br.

${ }^{2}$ Universidade Lúrio - UniLúrio, Faculdade de Ciências Agrárias, Departamento de produção e proteção vegetal, CEP: 1115-04, Unango - Niassa, Moçambique E-mail: serztjane@gmail.com
}

Rev. Bras. Biom., Lavras, v.38, n.3, p.369-384, 2020 - doi: 10.28951/rbb.v38i3.457 
- KEYWORDS: Biological interpretation; curvature measurements; nonlinear regression

\section{Introduction}

Growth curves are the result of measures taken over time, which can characterize the development of animal and plant species. In growth analyses, several statistical models are used, and nonlinear ones have better adjustments, since these models have the advantage of presenting fewer parameters, that is, they are more parsimonious, and have practical and biological interpretation (CASSIANO; SÁFADI, 2015; FERNANDES et al., 2015; RIBEIRO et al., 2018).

According to von Bertalanffy (1938), "growth" is the measurable increase of an organic system produced by the assimilation of materials obtained from its environment, making it clear that this phenomenon is extremely heterogeneous and complex. The author also reported that growth is largely dependent on external and internal factors. The author also observed that the weight growth curves as a function of time are S-shaped, with inflection point at about one third of the maximum weight.

The use of reparametrization in nonlinear regression models is common, since researchers reorganize the parameters so that they have more convenient interpretations with the study area of interest. However, some reparametrizations confuse readers, making the use of nonlinear regression more complicated. According to Cordeiro et al. (2009) and Diel et al. (2019), the model is not always expressed in an appropriate parametric form, which facilitates the convergence of iterative processes used to obtain the estimates of its parameters, being necessary to seek a more appropriate parameterization.

The parameterization used in the nonlinear model can directly affect its statistical properties, the validity of asymptotic inferences and the estimation of parameters. According to Fernandes et al. (2015), the inappropriate use of reparametrizations can impair the understanding of non-linear models. Thus, presenting calculations from the differential equation up to a general model can demystify the knowledge about the model, making it possible to obtain new parameterizations with specific interests for each area.

The estimation of parameters in nonlinear models, in general, is performed by minimizing the sum of squares of residuals, leading to a system of nonlinear normal equations, requiring obtaining estimates, the use of iterative methods that, in general, promote a linear approximation to estimate parameters, among which the Gauss-Newton's method stands out (LIMA et al., 2017; MANGUEIRA et al., 2016; SANTOS et al., 2013). Naturally, the smaller the nonlinearity present in the model, the closer to linear this approximation will be, making inferences about parameters more reliable (CORDEIRO et al., 2009; ZEVIANI et al., 2012; FERNANDES et al., 2015).

The nonlinearity measures of Bates and Watts (1980) are one of the ways to quantifying the nonlinearity present in a model, which do not depend on the scale of 
the response variable and serve both to evaluate the behavior of different data sets and of reparametrization of the same model. The authors quantified the nonlinearity present in models based on the geometric concept of curvature, and showed that this nonlinearity can be decomposed into two components: intrinsic nonlinearity $\left(c^{\iota}\right)$, which is specific to the model, that is, it practically does not change regardless of parameterization, and nonlinearity due to the effect of parameters $\left(c^{\theta}\right)$, which changes as parameterization changes, this measure being therefore the focus in the study of reparametrizations.

The aim of this study was to analytically develop the von Bertalanffy's model from its differential equation up to a general form and also to indicate, among reparametrizations most found in literature, which is the most adequate for this model, establishing the relationships among parameters in the different parameterizations.

\section{Material and methods}

Data analyzed were taken from Falcão et al. (2015), from an experiment conducted at "Capão da Onça" School Farm (FESCON) located at 2505'49 "S and $50^{\circ} 03$ ' $11^{\prime \prime} \mathrm{W}$, belonging to the State University of Ponta Grossa - UEPG, in the municipality of Ponta Grossa-PR. The property has area of 312.11 hectares, of which 6 hectares were used for the rearing of sheep in intensive farming. For the experiment, 31 Ile de France males were used, confined from birth to slaughter, at 120 days of age.

Animals were submitted to diet composed of concentrate (consisting of crushed corn, soybean meal, wheat bran, common salt, ammonium chloride and vitamin mineral supplement) 4 times a day, with average supply equivalent to $3 \%$ weight body. In addition, corn silage in an amount equivalent to $1.5 \mathrm{~kg} /$ animal / day was daily offered. Body weight was determined by biweekly weighing from February 2013 to June 2013, using mechanical mobile scale (brand: Açores; model: 602 SM) with $300 \mathrm{~kg}$ capacity. Weights considered were birth weight at 15, 30, 45, 60, 75, 90, 105 and 120 days of age, the latter being the slaughter weight. Weighing was carried out in the morning after a 12-h solid fasting period.

The von Bertanlanffy's model proposed by Ludwig von Bertalanffy in 1957 is a nonlinear model that presents the sigmoidal shape not symmetrical in relation to the inflection point. The model was initially used in the ecological area to model the growth of fish and crustaceans as a function of time. Von Bertalanffy quotes Putter (1920) in his article, who states that animal growth can be considered a result of the differential equation expressed by:

$$
\frac{d P}{d t}=\alpha P^{m}-\beta P^{n}
$$

where $P$ represents the weight of the animal as a function of time $t, \alpha$ and $\beta$ are anabolism and catabolism constants, respectively, and $m$ and $n$ are exponents that indicate values related with body weight $P$.

Rev. Bras. Biom., Lavras, v.38, n.3, p.369-384, 2020 - doi: 10.28951/rbb.v38i3.457 
Based on physiological facts, von Bertalanffy (1941) shows that, without any considerable loss of generality, $n$ can be considered equal to 1 . The $m=2 / 3$ value comes from an allometric relationship of weight with the body area of fish; however, there are authors who claim that this value may not be $2 / 3$; however, this discussion will not be taken into account in this work. So, the model proposed by Bertalanffy (1957) is as follows:

$$
\left\{\begin{array}{r}
\frac{d P}{d t}=\alpha P^{2 / 3}-\beta P \\
P(0)=P_{0}
\end{array}\right.
$$

where $P=P(t)$ is the fish mass as a function of time t, $\alpha$ is the anabolism constant, $\beta$ is the catabolism constant, $P_{0}$ is the initial mass.

In order to obtain a generalized expression for the von Bertalanffy's model, the $m$ exponent will be considered in solving the model's differential equation. The nonlinear equation (1) is of Bernoulli type and can be solved with a substitution of variables, thus leading to a linear equation (BASSANEZI, 2002). Thus, taking $Z=P^{1-m}$, we have:

$$
\begin{gathered}
\left\{\begin{array}{c}
\frac{d Z}{d t}=(1-m) P^{-m} \frac{d P}{d t} \\
Z(0)=P_{0}^{1-m}
\end{array}\right. \\
\frac{d Z}{d t}=(1-m) P^{-m}\left(\alpha P^{m}-\beta P\right) .
\end{gathered}
$$

Replacing $Z=P^{1-m}$ again:

$$
\begin{aligned}
\frac{d Z}{d t} & =(1-m)\left(\alpha-\beta P^{1-m}\right)=(1-m)(\alpha-\beta Z) \\
& =\alpha-\beta Z-m \alpha+\beta Z m \\
& =\alpha(1-m)-\beta(1-m) Z
\end{aligned}
$$

So:

$$
\frac{d Z}{d t}+\beta(1-m) Z=\alpha(1-m)
$$

The result obtained corresponds to a linear Ordinary Differential Equation (ODE) of $1^{\text {st }}$ order not homogeneous in Z. Therefore:

$$
\frac{d Z}{d t}+\beta(1-m) Z=\alpha(1-m)
$$


ODE of the form:

$$
y^{\prime}(x)+p(x) y(x)=g(x) .
$$

Multiplying ODE by $u(t)$ :

$$
u(t) Z^{\prime}(t)+u(t) \beta(1-m) Z(t)=u(t) \alpha(1-m),
$$

and defining: $u^{\prime}(x)=u(x) p(x)$, we have:

$u^{\prime}(t)=u(t) \beta(1-m)$, so:

$$
u(t) Z^{\prime}(t)+u^{\prime}(t) Z(t)=u(t) \alpha(1-m) .
$$

Since: $d[u(x) y(x)]=u(x) g(x)$, so:

$$
d[u(t) Z(t)]=u(t) \alpha(1-m),
$$

and $u(x) g(x)=\int u(x) g(x) d x+C$, therefore:

$$
(t) Z(t)=\int u(t) \alpha(1-m) d t+C
$$

The $Z(t)$ expression can be obtained by:

$$
Z(t)=\frac{\int u(t) \alpha(1-m) d t}{u(t)},
$$

Since $u^{\prime}(t)=u(t) \beta(1-m) \Leftrightarrow \frac{d u(t)}{d t}=u(t) \beta(1-m)$.

To obtain the integrating factor $u(x)$, we return to:

$$
\frac{d u(x)}{d x}=u(x) p(x)
$$

Using the variable separation method, we rewrite this equation in the form:

$$
\frac{d u(x)}{u}=p(x) d x \Rightarrow \ln (u)=\int p(x) d x+K,
$$

$u(x)=\exp \left(\int p(x) d x\right)$.

Returning to the development of the model, we have:

$$
\begin{gathered}
\frac{d u}{u}=\beta(1-m) d t \Rightarrow \ln (u(t))=\int \beta(1-m) d t, \\
u(t)=\exp \left(\int \beta(1-m) d t\right) .
\end{gathered}
$$

Then, replacing (2) in (1), we have: 


$$
Z(t)=\frac{\left[\int \exp \left(\int \beta(1-m) d t\right) \alpha(1-m) d t+C\right]}{\exp \left(\int \beta(1-m) d t\right)} .
$$

It is known that:

$$
\int \beta(1-m) d t=\beta(1-m) t,
$$

Therefore, substituting in the expression $Z(t)$, we obtain:

$$
\begin{aligned}
Z(t) & =\frac{\int \exp (\beta(1-m) t) \alpha(1-m) d t+C}{\exp \left(\int \beta(1-m) d t\right)} \\
& =\frac{\alpha}{\beta}+C \exp (-\beta(1-m) t) .
\end{aligned}
$$

Since $Z(t)=P(t)^{1-m}$, we have:

$$
\begin{aligned}
P(t) & =[Z(t)]^{\frac{1}{1-m}} \\
& =\left[\frac{\alpha}{\beta}+C \exp (-\beta(1-m) t)\right]^{\frac{1}{1-m}} .
\end{aligned}
$$

Putting $\frac{\alpha}{\beta}$ into evidence, we obtain:

$$
\begin{aligned}
P(t) & =\left[\left(\frac{\alpha}{\beta}\right)\left(1+C \frac{\beta}{\alpha} \exp (-\beta(1-m) t)\right)\right]^{\frac{1}{1-m}} \\
& =\left(\frac{\alpha}{\beta}\right)^{\frac{1}{1-m}}\left(1+\frac{\beta}{\alpha} C \exp (-\beta(1-m) t)\right)^{\frac{1}{1-m}} .
\end{aligned}
$$

By definition, it is known that:

$$
P_{\infty}=\lim _{t \rightarrow \infty} P(t),
$$

Therefore, substituting in the expression of $P(t)$ :

$$
\begin{aligned}
P_{\infty} & =\lim _{t \rightarrow \infty}\left(\frac{\alpha}{\beta}\right)^{\frac{1}{1-m}}\left(1+\frac{\beta}{\alpha} C \exp (-\beta(1-m) t)\right)^{\frac{1}{1-m}} \\
& =\left(\frac{\alpha}{\beta}\right)^{\frac{1}{1-m}} \lim _{t \rightarrow \infty}\left(1+\frac{\beta}{\alpha} C \exp (-\beta(1-m) t)\right)^{\frac{1}{1-m}} .
\end{aligned}
$$

It is known that:

$$
\lim _{t \rightarrow \infty}\left(1+\frac{\beta}{\alpha} C \exp (-\beta(1-m) t)\right)^{\frac{1}{1-m}}=1,
$$


then:

$$
P_{\infty}=\left(\frac{\alpha}{\beta}\right)^{\frac{1}{1-m}} .
$$

Given the initial condition $P(0)=P_{0}$, we have:

$$
\begin{aligned}
P(t)= & \left(\frac{\alpha}{\beta}\right)^{\frac{1}{1-m}}\left(1+C \frac{\beta}{\alpha} \exp (-\beta(1-m) t)\right)^{\frac{1}{1-m}}, \\
P_{0} & =P_{\infty}\left(1+C \frac{\beta}{\alpha} \exp (-\beta(1-m) t)\right)^{\frac{1}{1-m}} \\
& =P_{\infty}\left(1+C \frac{\beta}{\alpha}\right)^{\frac{1}{1-m}} \\
& \Rightarrow\left(1+C \frac{\beta}{\alpha}\right)^{\frac{1}{1-m}}=\frac{P_{0}}{P_{\infty}} \\
& \Rightarrow\left(1+C \frac{\beta}{\alpha}\right)=\left(\frac{P_{0}}{P_{\infty}}\right)^{1-m},
\end{aligned}
$$

where the $C$ value is obtained, given by:

$$
C=\left[\left(\frac{P_{0}}{P_{\infty}}\right)^{1-m}-1\right] \frac{\alpha}{\beta} .
$$

Substituting the $C$ constant in expression (4), the generalized model for the weight growth of any animal is obtained:

$$
P(t)=P_{\infty}\left\{1+\left[\left(\left(\frac{P_{0}}{P_{\infty}}\right)^{1-m}-1\right) \exp (-\beta(1-m) t)\right]\right\}^{\frac{1}{1-m}}
$$

The three models to be considered in this work with different parameterizations start from the generalized model presented in (5). Then, its mathematical development will be presented until reaching a more well-known functional form and close to that found in literature.

Multiplying and dividing $\left[\left(\frac{P_{0}}{P_{\infty}}\right)^{1-m}-1\right]$ by $(m-1)$ :

$$
P(t)=P_{\infty}\left\{1+\left[\frac{\left(\frac{P_{0}}{P_{\infty}}\right)^{1-m}-1}{(m-1)}(m-1) \exp (-\beta(1-m) t)\right]\right\}^{\frac{1}{1-m}}
$$

Considering the exponential property: $a=\exp ^{\ln a}$ and making $a=$ $\frac{\left(\frac{P_{0}}{P_{\infty}}\right)^{1-m}-1}{(m-1)}$, then: 


$$
\begin{aligned}
P(t) & =P_{\infty}\left\{1+\left[(m-1) \exp \left(\ln \frac{\left(\frac{P_{0}}{P_{\infty}}\right)^{1-m}-1}{(m-1)}\right) \exp (-\beta(1-m) t)\right]\right\}^{\frac{1}{1-m}} \\
& =P_{\infty}\left\{1+\left[(m-1) \exp \left(\ln \frac{\left(\frac{P_{0}}{P_{\infty}}\right)^{1-m}-1}{(m-1)}+(-\beta(1-m) t)\right)\right]\right\}^{\frac{1}{1-m}}
\end{aligned}
$$

Putting $-\beta(1-m)$ in evidence and rearranging the $P(t)$ expression, we have:

$$
\begin{aligned}
P(t) & =P_{\infty}\left\{1+\left[( m - 1 ) \operatorname { e x p } \left(-\beta(1-m)\left(\frac{\left.\left.\left.\left.\ln \frac{\left(\frac{P_{0}}{P_{\infty}}\right)^{1-m}-1}{(m-1)}+t\right)\right)\right]\right\}^{\frac{1}{1-m}}}{-\beta(1-m)}+t\right)\right.\right.\right. \\
& =P_{\infty}\left\{1+\left[(m-1) \exp \left(-\beta(1-m)\left(\frac{\ln \left(\frac{(m-1)}{\left(\frac{P_{0}}{P_{\infty}}\right)^{1-m}-1}\right)^{-1}}{-\beta(1-m)}+t\right)\right)\right]\right\}^{\frac{1}{1-m}} .
\end{aligned}
$$

Using the logarithm power property, we have:

$$
P(t)=P_{\infty}\left\{1+\left[(m-1) \exp \left(-\beta(1-m)\left(+\frac{\ln \frac{(m-1)}{\left(\frac{P_{0}}{P_{\infty}}\right)^{1-m}-1}}{\beta(1-m)}+t\right)\right)\right]\right\}^{\frac{1}{1-m}}
$$

Equation (5) presents the general expression considering the original parameters of the von Bertalanffy's model. As already shown, $P_{\infty}=\lim _{t \rightarrow \infty} P(t)=$ $a$ is the model's asymptote. Deriving the expression twice in relation to $t$ and equaling zero, we will have the abscissa of the inflection point $b$, which is given by:

$$
b=\left[-\frac{\ln \frac{(m-1)}{\left(\frac{P_{0}}{P_{\infty}}\right)^{1-m}-1}}{\beta(1-m)}\right] .
$$

Finally, the growth rate $k$ is the term that appears in evidence in the exponential and is given by:

$$
k=\beta(1-m) .
$$

Thus, it is possible to rewrite the expression (6), reaching the functional form already known in literature: 


$$
y_{i}=a\left\{1+\left[(m-1) \exp \left[-k\left(t_{i}-b\right)\right]\right]\right\}^{\frac{1}{1-m}} .
$$

Where $y_{i}$ is the response variable, which in the case of this study is the weight and $t_{i}$ is the $i$-th time $t$, knowing that the $i$ index varies from the first to the last observation of the time vector. In this study, we have $m=2 / 3$ for all parameterizations, as is commonly found in literature and originally proposed in von Bertalanffy (1957), in the study on fish and crustaceans. There are authors who claim that the $m$ value can vary, since the analyses by Ohnishi et al. (2014) showed that this allometric value would be approximately within the range from $2 / 3$ to 1 .

Thus, the parameterizations of the von Bertalanffy's model compared in this work are shown in Table 1:

Table 1 - Parameterizations of the von Bertalanffy (1957) model found in the literature

\begin{tabular}{cc}
\hline Parameterizations & Models \\
\hline Parameterization 1 & $y_{i}=a *\left(1-b * \exp \left(-k * x_{i}\right)\right)^{3}+\varepsilon_{i}$. \\
Parameterization 2 & $y_{i}=a *\left(1-\frac{\exp \left(k *\left(b-x_{i}\right)\right)}{3}\right)^{3}+\varepsilon_{i}$. \\
Parameterization 3 & $y_{i}=a *\left(1-\exp \left(-b-k * x_{i}\right)\right)^{3}+\varepsilon_{i}$. \\
\hline
\end{tabular}

In parameterizations shown, it is known that for $i=1,2, \ldots, n ; y_{i}$ is the $i$-th observation of the dependent variable, $x_{i}$ is the $i$-th observation of the independent variable; $a$ is the asymptotic value, that is, the expected value for the maximum growth of the object under study, when $x_{i} \rightarrow \infty ; b$ is associated with the abscissa of the inflection point; $k$ is the maturity or precocity index associated with growth, and the higher its value, the less time it will take for the object under study to reach the asymptotic value $(a) ; \varepsilon_{i}$ is the random error associated with the $i$-th observation, which is assumed to be independent and identically distributed following a normal distribution of zero mean and constant variance, that is, $\varepsilon_{i} \sim N\left(0, \sigma^{2}\right)$.

It is very important to check the model suitability, and for that, an analysis of residuals must be performed. These analyses can be graphical or by means of statistical tests such as those of Shapiro-Wilk (SW), Durbin-Watson (DW) and Breusch-Pagan (BP) to verify normality, independence and homoscedasticity assumptions, respectively.

To analyze the normality of the residue vector, the Shapiro-Wilk test was used, in which the hypotheses used in the test are:

$$
\begin{aligned}
& H_{0} \text { : Residuals have normal distribution; } \\
& H_{1} \quad \text { : Residuals do not have normal distribution. }
\end{aligned}
$$

The function used in the $\mathrm{R}$ software (R Core Team, 2019) was shapiro.test, in which, if the p-value is less than the $\alpha$ significance level, $H_{0}$ is rejected.

Rev. Bras. Biom., Lavras, v.38, n.3, p.369-384, 2020 - doi: 10.28951/rbb.v38i3.457 
To analyze the assumption of independence, that is, if there is residual autocorrelation, the Durbin-Watson test was used, in which the tested hypotheses are:

$$
\begin{aligned}
& H_{0}: \text { Residuals are independent; } \\
& H_{1} \text { : Residuals show autocorrelation. }
\end{aligned}
$$

The function used in the $\mathrm{R}$ software ( $\mathrm{R}$ Core Team, 2019) was durbinWatsonTest, in which, if the p-value is less than the $\alpha$ significance level, $H_{0}$ is rejected.

Finally, the test chosen to verify the homogeneity assumption of variances was the Breusch-Pagan, in which the hypotheses used in the test are:

$$
\begin{aligned}
& H_{0}: \text { There is homogeneity in residual variances; } \\
& H_{1} \quad \text { : There is no homogeneity in residual variances. }
\end{aligned}
$$

The function used in the R software (R CORE TEAM, 2019) was bptest, in which, if the p-value is less than the $\alpha$ significance level, $H_{0}$ is rejected. As it is an analysis for variances, the calculated value must be compared with the critical value of the chi-square distribution, with 1 degree of freedom.

To evaluate the fit quality of models, the nonlinearity measures described by Bates and Watts (1980) were used, with $c^{\iota}$ being the intrinsic nonlinearity and $c \theta$ the parametric nonlinearity, which were obtained by the rms.curv function of the $\mathrm{R}$ software and the Snedecor F distribution is given by $F(0.95 ; p ; n-p)$, where $p$ is the number of parameters and $n$ the sample size. Concomitant with nonlinearity measures, quality evaluators were used: determination coefficient $\left(R^{2}=1-\frac{S Q R}{S Q T}\right)$

and the corrected Akaike information criterion $\left(A I C c=\frac{A I C+(2 p(p+1))}{(n-p-1))}\right)$, where: $\mathrm{SQR}$ is the sum of squared residuals; SQT is the sum of the total square; $\mathrm{n}$ is the sample size; $\mathrm{p}$ is the number of parameters and AIC is the Akaike information criterion $\left(A I C=n * \ln \left(\frac{S Q R}{n}\right)+2 p\right)$, with $\ln$ being the natural logarithm operator. These evaluators were obtained using the following functions $R s q$ and $A I C c$ from the AICcmodavg package, respectively, in the R software (R Core Team, 2019).

\section{Results}

Through the SW, DW and BP tests to assess normality, independence and homogeneity assumptions, respectively, no violation of residuals was observed at $5 \%$ significance level, considering the three parameterizations of the von Bertalanffy's model, that is, no test rejected $H_{0}$, as can be seen in Table 2 .

Subsequently, the parameters for the three parameterizations of the von Bertalanffy's model were estimated, all of which are significant at $5 \%$ for the description of the sheep weight growth, which is shown in Table 3. 
Table 2 - Shapiro-Wilk (SW), Durbin-Watson (DW) and Breusch-Pagan (BP) tests, with the respective p-values, applied to the residuals of the adjusted models

\begin{tabular}{cccc}
\hline Test & Param.*1 & Param.2 & Param.3 \\
\hline SW & 0.9523 & 0.9523 & 0.9523 \\
DW & 0.3720 & 0.4460 & 0.4120 \\
BP & 0.3702 & 0.3702 & 0.3702 \\
\hline \multicolumn{3}{c}{ *Param. = Parameterization. }
\end{tabular}

Table 3 - Estimated parameters for the three von Bertalanffy models (1957), with the respective standard errors (SE), under study, for the description of sheep weight growth

\begin{tabular}{ccccccc}
\hline Parameter & Param.* $^{*} 1$ & SE & Param. 2 & SE & Param. 3 & SE \\
\hline$a$ & 47.9336 & 2.6283 & 47.9336 & 2.6283 & 47.9336 & 2.6283 \\
$b$ & 0.5485 & 0.0117 & 32.2988 & 2.7776 & 0.6005 & 0.0214 \\
$k$ & 0.0154 & 0.0013 & 0.0154 & 0.0013 & 0.0154 & 0.0013 \\
\hline *Param. = Parameterization.
\end{tabular}

As shown by Fernandes et al. (2015) and Diel et al. (2019), Table 3 shows that $a$ and $k$ parameters have the same values for all parameterizations and have different values for the $b$ parameter for each parameterization.

Parameterization 1 of the von Bertalanffy's model (1957) is the one generally found in literature for adjusting growth curves. Although widely used, this parameterization does not provide a direct interpretation for the $b$ parameter, the abscissa of the inflection point being given by: $\frac{1}{k} \ln (3 b)$. That is, in this model, the $b$ estimate is not exactly the inflection point.

Parameterization 2 is presented so that the $b$ parameter can be interpreted as the abscissa of the inflection point. As for Parametrization 3, the $b$ parameter also has no direct interpretation and the abscissa of the inflection point can be found by the following transformation: $\frac{\ln (3)-b}{k}$.

According to Fernandes et al. (2015), many authors choose parameterizations simply because they are the most common, without considering the fact that some require greater computational effort, as these parameterizations need higher number of iterations to achieve convergence, which can compromise the quality of adjustments, since they are distant from linearity, thus impairing inferences about parameters.

In this study, the following fit quality evaluators were analyzed: $R^{2}, A I C c$, $\sqrt{F} * c^{\iota}, \sqrt{F} * c^{\theta}, c^{\iota}$ and $c^{\theta}$ for the three parameterizations, which are shown in Table 4 .

Table 4 shows that the $R^{2}$ value is close to 1 , which indicates good fit of models, that is, they explain data variability well; however, due to its characteristic, $A I C c$ cannot tell in this case which is the best model. As there are different parameterizations for the same model, the $R^{2}$ and $A I C c$ values do not differ from

Rev. Bras. Biom., Lavras, v.38, n.3, p.369-384, 2020 - doi: 10.28951/rbb.v38i3.457 
each other (FERNANDES et al., 2015).

Table 4 - Goodness-of-fit test for the three parameterizations of von Bertalanffy's model (1957), in the description of sheep weight growth

\begin{tabular}{ccrrr}
\hline Animal & Criteria & Param. 1 & Param. 2 & Param. 3 \\
\hline \multirow{6}{*}{ Sheep } & $R^{2}$ & 0.9978 & 0.9978 & 0.9978 \\
& $A I C c$ & 31.1405 & 31.1405 & 31.1405 \\
& $\sqrt{F} * c^{\iota}$ & 0.0445 & 0.0445 & 0.0445 \\
& $\sqrt{F} * c^{\theta}$ & 2.0296 & 1.4957 & 2.0443 \\
& $c^{\iota}$ & 0.0204 & 0.0204 & 0.0204 \\
& $c^{\theta}$ & 0.9306 & 0.6857 & 0.9373 \\
\hline
\end{tabular}

${ }^{*}$ Param. $=$ Parameterization.

According to Diel et al. (2019), as parameter estimates are related to data, great care must be taken when selecting a model, as it will be through the interpretation of these values that inference statistics will be performed. Therefore, criteria such as $R^{2}$ and $A I C c$ can be used; however, with attention to intrinsic and parametric nonlinear curvature measurements.

What differs is the measurement of parametric nonlinearity $c^{\theta}$ and consequently $\sqrt{F} * c^{\theta}$, which has lower value for parameterization 2 , indicating that it is the most suitable for Ile de France sheep weight growth data, for having more reliable estimates.

According to Bates and Watts (1980), measurements of $c^{\theta}$ curvature can be compared to a linear curvature of $95 \%$ confidence region with the critical $\frac{1}{\sqrt{F(0,95 ; p ; n-p)}}$ value, in this case the value is 0.4585 . All parameterizations obtained $c^{\theta}$ value greater than the critical value; however, parameterization 2 does not present such a large distance from linearity in relation to the others, that is, choosing this parameterization results in less quality compromise of estimates as inferences about parameters.

The $\sqrt{F} * c^{\iota}$ evaluator, also used by El-Shehavvy (2008), expresses a derivation of the surface tangent plane. This deviation expressed as a percentage of the confidence radius is $100(1-\sqrt{1-\sqrt{F} * c} / \sqrt{F} * c)$; therefore, the $\sqrt{F} * c=0.2$ value causes a $10 \%$ surface deviation of the confidence radius. Since $\sqrt{F} * c^{\iota}$ is small, there is deviation below $10 \%$ between the expected surface and the tangent plane that approaches in the confidence radius, indicating that the approach by a plane in the neighborhood of estimates can be considered satisfactory.

Figure 1 shows the graph for the adjustments of three parameterizations of the von Bertalanffy's model to sheep growth data, which is possible to identify the sigmoidal format of the development of this species. It can be observed that the lines of adjustments for the three forms of the von Bertalanffy's model are superimposed; therefore, this study did not take into account the graphical analysis of models to select the best one. 


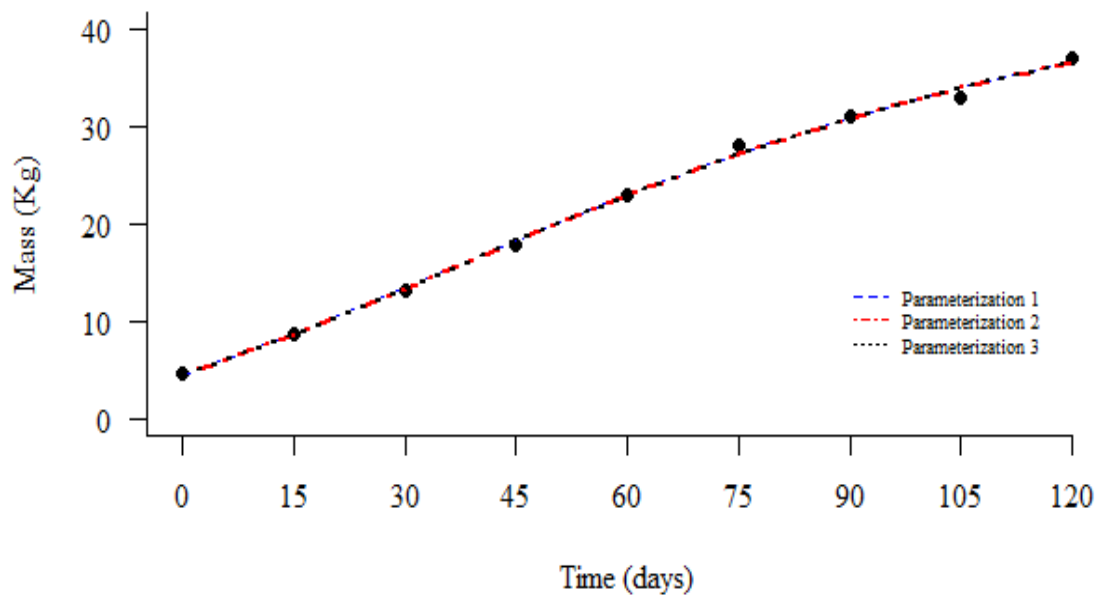

Figure 1 - Fittted curve of the three parameterizations of the von Bertalanffy model to the data of weight growth (in kilograms) of the sheep.

In practice, models without practical or biological interpretation for the $b$ parameter is frequencing, as in the works of Santoro et al. (2005), Silva et al. (2011), Silveira et al. (2011), Cassiano and Sáfadi (2015), Jacob et al. (2015), Lima et al. (2017), Rodrigues et al. (2018) and Diel et al. (2019). However, if parameterization 2 is used, the quality of adjustment may be similar, but the practical interpretation of parameter $b$ is gained. It is also noteworthy that the most appropriate parameterization of a model depends on the researcher's interest, using parameters that provide useful information to the problem under study.

\section{Conclusion}

Choosing the parameterization with smaller parametric nonlinearity measure influences the reliability and inferences about estimated parameters. Therefore, the study of these nonlinearity measures is of importance in growth curves that use nonlinear models.

Parameterization in which the $b$ estimate represents the abscissa of the inflection point should be preferred, as it provides direct biological interpretation for the three parameterizations of the model and, in the case of the growth of Ile de France sheep, it presents the lowest values for parametric nonlinearity. 


\section{Acknowledgments}

Authors would like to thank CAPES for scholarships granted to the first and second authors, respectively, the CNPq for the financial assistance, and editors and reviewers for their comments and suggestions.

FERNANDES, F. A.; SILVA, E. M.; LIMA, K. P.; JANE, S. A.; FERNANDES, T. J.; MUNIZ, J. A. Parametrizações do modelo de von Bertalanffy para a descrição de curvas de crescimento. Rev. Bras. Biom., Lavras, v.38, n.3, p.369-384, 2020.

- RESUMO: As curvas de crescimento de animais, em geral, possui formato de "S", conhecidas também como curvas sigmoidais. Este tipo de curva é bem ajustada por modelos de regressão não linear, dentre eles o de von Bertalanffy que tem sido muito aplicado em diversas áreas, sendo apresentado na literatura por meio de diferentes parametrizações, que na prática, pode além de complicar seu entendimento, afetar as medidas de não linearidade e as inferências sobre os parâmetros. Para quantificar a não linearidade presente em um modelo Bates e Watts utilizaram um conceito geométrico de curvatura. O objetivo deste trabalho foi desenvolver analiticamente três parametrizações do modelo não linear de von Bertalanffy, referente à sua não linearidade, as implicações nas inferências e estabelecer relações entre os parâmetros nas diferentes formas de expressar os modelos. Estas as parametrizações foram ajustadas à dados de crescimento de ovinos. Para cada parametrização foram calculadas as medidas de curvatura intrínseca e paramétrica descritas por Bates e Watts. A escolha da parametrização afeta as medidas de não linearidade, consequentemente, influencia na confiabilidade e nas inferências sobre os parâmetros estimados. As formas mais utilizadas na literatura apresentaram os maiores afastamentos da linearidade, evidenciando a importância de se analisar estas medidas em qualquer estudo sobre curva de crescimento. Deve ser utilizada a parametrização na qual a estimativa de $b$ representa a abscissa do ponto de inflexão por apresentar menores desvios de linearidade e interpretação biológica direta para todos os parâmetros.

- PALAVRAS-CHAVE: Interpretação biológica; medidas de curvatura; regressão não linear.

\section{References}

BASSANEZI, R. C.. Ensino-aprendizagem com modelagem matemática. 3.ed. São Paulo: Editora Contexto, v.2000, 2002. 389p.

BATES, D. M.; WATTS, D. G. Relative curvature measures of nonlinearity: with discussion. Journal of the Royal Statistical Society, v.42, n.1, p.1-25, 1980.

CASSIANO, F. R.; SÁFADI, T. Modelos de crescimento animal para tempos irregulares. Pesquisa Agropecuária Brasileira, v.50, n.11, p.1114-1119, 2015. 
CORdeiro, G. M.; PRUDEnTE, A. A.; DEMÉtRIO, C. G. B. Uma revisão dos modelos normais não-lineares. Revista Brasileira de Biometria, v.27, n.3, p.360-393, 2009.

DIEL, M. I., SARI B. G., KRYSCZUN D. K., OLIVOTO T., PINHEIRO M. V. M., MEIRA D., SCHMIDT D., LÚCIO A. D. Nonlinear regression for description of strawberry (Fragaria x ananassa) production. The Journal of Horticultural Science and Biotechnology, v.94, n.2, p.259-273, 2019.

EL-SHEHAVVY, S. A. On the selection of models in nonlinear regression. Asian Journal of Mathematics and Statistics, v.1, n.1, p.1-13, 2008.

FALCÃO, P. F.; PEDROSA, V. B.; MOREIRA, R. P.; SIEKLICKI, M. F.; ROCHA, C. G.; SANTOS, I. C.; FERREIRA, E. M.; MARTINS, A. S. Curvas de crescimento de cordeiros da raça Ile de France criados em confinamento. Revista Brasileira de Saúde e Produção Animal, v.16, n.2, p.377-386, 2015.

FERNANDES, T. J.; MUNIZ, J. A.; PEREIRA A. A.; MUNIZ, F. R.; MUIANGA C. A. Parameterization effects in nonlinear models to describe growth curves. Acta Scientiarum. Technology, v.37, n.4, p.397-402, 2015.

JACOB, N.; GANESAN, R.; SREEKUMAR, D. Nonlinear growth model in rabbits. The Indian Veterinary Journal, v.92, p.23-26, 2015.

LIMA, K. P.; DE MORAIS, A. R.; VIEIRA N. M. B.; VILLA F.; ANDRADE M. J. B. Uso de modelos não lineares na descrição do acúmulo de boro em diferentes partes do feijoeiro cultivar Jalo. Revista Brasileira de Biometria, v.35, n.4, p.834-861, 2017.

MANGUEIRA, R. A. F.; SAVIAN, T. V.; MUNIZ, J. A.; SERMARINI, R. A.; NETTO, J. C. O modelo logístico considerando diferentes distribuições para os erros aplicado a dados de altura de milho. Revista Brasileira de Biometria, v.34, p.317-333, 2016.

OHNISHI, S.; YAMAKAWA, T.; AKAMINE, T. On the analytical solution for the Pütter-Bertalanffy growth equation. Journal of theoretical biology, v.343, p.174-177, 2014.

R CORE TEAM. $R$ : A language and environment for statistical computing.Vienna; R Foundation for Statistical Computing, 2017. Accessible at: ¡https://www.rproject.org/i. Accessed on: Jan. 2019.

RIBEIRO, R. A. et al. Growth curve for height at withers of Mangalarga Marchador horses with heterocedasticity. Arquivo Brasileiro de Medicina Veterinária e Zootecnia, v.70, n.1, p.272-278, 2018.

RODRIGUES, A.; CHAVES, L. M.; SILVA, F. F.; GARCIA, I. P.; DUARTE, D. A. S.; VENTURA, H. T. Isotonic regression analysis of Guzerá cattle growth curves. Revista Ceres, v.65, n.1, p.24-27, 2018. 
SANTORO, K. R.; BARBOSA, S. B. P.; BRASIL, L. H. A.; SANTOS, E. S. Estimativas de parâmetros de curvas de crescimento de bovinos zebu, criados no estado de Pernambuco. Revista Brasileira de Zootecnia, v.34, n.6, p.2262-2279, 2005.

SANTOS, A.; SAVIAN, T.V.; MUNIZ, J.A. Regressão não linear no desdobramento da interação em experimentos com parcela subdividida no tempo. Revista Brasileira de Biometria, v.31, p.379-396, 2013.

SILVA, F. L.; ALENCAR, M. M.; FREITAS, A. R.; PACKER, I. U.; MOURÃO, G. B. Curvas de crescimento em vacas de corte de diferentes tipos biológicos. Pesquisa Agropecuária Brasileira, v.46, p.262-271, 2011.

SILVEIRA, F. G.; SILVA, F. F.; CARNEIRO, P. L. S.; MALHADO, C. H. M.; MUNIZ, J. A. Análise de agrupamento na seleção de modelos de regressão nãolineares para curvas de crescimento de ovinos cruzados. Ciência Rural, v.41, n.4, p.692-698, 2011.

von BERTALANFFY, L. A quantitative theory of organic growth (inquiries on growth laws. II). Human biology, v.10, n. 2, p.181-213, 1938.

von BERTALANFFY, L. Untersuchungen über die Gesetzlich- keit des Wachstums. VII, Stoffwechseltypen und Wachstumstypen. Biol. Zentralbl, v.61, p.510-532, 1941.

von BERTALANFFY, L. Quantitative laws in metabolism and growth. The quarterly review of biology, v.32, n.3, p. 217-231, 1957.

ZEVIANI, W. M.; SILVA, C. A.; CARNEIRO, W. J. O.; MUNIZ, J. A. Modelos não lineares para a liberação de potássio de estercos animais em latossolos. Ciência Rural, v.42, n.10, p.1789-1796, 2012.

Received on 23.10.2019.

Approved after revised on 20.05.2020. 